\title{
MODEL EGZEGEZY W DZIELE JOSEPHA RATZINGERA - BENEDYKTA XVI JEZUS Z NAZARETU CZ. 1
}

We współczesnym świecie, który w różnych sferach życia promuje i dowartościowuje pluralizm, może zrodzić się refleksja nad naukowymi metodami badawczymi - także tymi, których celem jest przybliżenie do prawdy objawionej w słowie Bożym. Różnorodność metod egzegezy biblijnej jest wprost imponująca - i wydaje się, że powinna ona pomagać w podejmowaniu prób zrozumienia i wniknięcia w tajemnicę słowa, które Bóg kieruje do człowieka. Czy jednak wielość tych metod daje szansę bardziej zbliżyć się do odkrywania Prawdy czy raczej niesie ryzyko pogubienia się w mnogości wypracowanych rozwiązań? W poszukiwaniu odpowiedzi na pytanie, jaka jest z katolickiego punktu widzenia najbardziej optymalna, bezpieczna i pogłębiająca wiarę egzegeza biblijna, odwołam się do drogi interpretacji Pisma Świętego obranej przez kard. Józefa Ratzingera - Benedykta XVI w dziele Jezus z Nazaretu (cz. 1). ${ }^{1}$

We Wstępie autor czyni ważne założenia. Jezus z Nazaretu to efekt własnych wewnętrznych poszukiwań, którymi - w formie książki wydanej już za jego pontyfikatu - dzieli się z czytelnikami. Benedykt XVI zaznacza, że nie jest to wypowiedź Nauczycielskiego Urzędu Kościoła. Wyrażając wdzięczność za dokonania współczesnej

1 Na temat podejścia współczesnej postmodernistycznej cywilizacji do istnienia stałych zasad, tradycji, odrzucenia idei obiektywnej prawdy oraz badań dotyczących podejścia do kwestii interpretacji Biblii zob. J. K rę c i dło, Jak czytać i interpretować Biblię w postmodernistycznym świecie, Przez Maryję ku Wcielonemu Słowu 5/2012, s. 15-29. 
egzegezy, proponuje nowe podejście metodologiczne, które zawiera w sobie otwartość na historyczne spojrzenie na Biblię przy jednoczesnej jej teologicznej interpretacji. Powołując się na Divino afflante Spiritu (1943), Konstytucję Dei Verbum oraz dokumenty Papieskiej Komisji Biblijnej Interpretacja Pisma Świętego w Kościele (1993) i Naród żydowski i jego Pisma Święte w Biblii chrześcijańskiej (2001), zaznacza konieczność korzystania z metody historyczno-krytycznej oraz wskazuje na pewne jej ograniczenia i potrzebę sięgania także po inne metody. Dla Benedykta XVI kluczową zasadą teologicznej egzegezy Pisma Świętego jest oparcie się na głównym założeniu egzegezy kanonicznej, mianowicie na jedności całego Pisma Świętego, oraz na bezwarunkowym przyjęciu, że klamrą łącząca Stary i Nowy Testament jest Osoba Jezusa Chrystusa i tajemnica Jego Bóstwa, która pociąga za sobą wiarę w Niego. ${ }^{2}$

\section{Egzegeza kanoniczna}

Punktem wyjścia metody kanonicznej jest przede wszystkim perspektywa wiary i traktowanie Biblii jako całości. Interpretując dany tekst biblijny, patrzy się na niego jak na fragment kanonu Pisma Świętego. Takie postrzeganie Biblii - jako normy wiary dla społeczności ludzi wierzących - pozwala na aktualizację słowa Bożego także w naszych czasach. ${ }^{3} \mathrm{~W}$ dziele Jezus z Nazaretu założenia powyższej metody są regularnie stosowane - na co wskażą poniższe przywołania.

Odwołując się do ksiąg Starego i Nowego Testamentu, papież zbliża się do zrozumienia Osoby Chrystusa, którego zapowiadali prorocy. Na przykład, omawiając tajemnicę chrztu Jezusa nad Jordanem, Benedykt XVI, idąc również za głosem Ojców Kościoła,

2 Por. J. R a t z i ng e r-B e n e d y k t XVI, Jezus z Nazaretu, cz. 1, Kraków 2007, s. 5-15.

3 Por. Z. N i e m i r s k i, Nowa egzegeza. W trosce o wiare i proforystyke, w: D. S k rok a, D. S w e n d a (red.), Teologiczne refleksje po lekturze ksiażki Josepha Ratzingera Benedykta XVI ,Jezus z Nazaretu”, Kraków 2009, s. 40-43. 
dostrzega analogię do namaszczenia królów i kapłanów w Starym Testamencie. Zauważa, że już prorok Izajasz zapowiadał pojawienie się Pomazańca, na którego zstąpi Duch Pański (Iz 11,2). Sam Jezus, według relacji św. Łukasza, w synagodze w Nazarecie przedstawił siebie jako tego, na którym spoczął i którego namaścił Duch Pański (por. Łk 4,18; Iz 61,1). Autor przywołuje jeszcze proroka Izajasza, gdy podejmuje kwestię tajemnicy Chrystusowego krzyża. ${ }^{4}$

Rozważając fragment Mt 5,17 - 7,27, Jezusowe Kazanie na Górze, Benedykt XVI przywołuje z kolei teksty nowotestamentalne. W poszukiwaniu odpowiedzi na pytanie: jak dobrze zrozumieć antytezę „przodkom powiedziano - a Ja wam mówię", nawiązuje zarówno do Listu św. Pawła do Galatów - w którym apostoł wyjaśnia wątpliwości dotyczące zachowywania Tory w całości - jak i wskazuje na konieczność podążania za uniwersalizmem ludu Bożego. O przynależności do tego ludu decyduje zaś już nie tylko cielesne pochodzenie od Abrahama, ale wiara i wspólnota życia z Jezusem Chrystusem. Mając na uwadze, że zarówno św. Mateusz jak i św. Paweł kierowali swoje słowa do judeochrześcijan, Benedykt XVI zauważa wierność Boga względem siebie oraz wierność Jezusa wobec wiary objawionej przodkom. Chrystus jest przedstawiany jako ten, który dokonuje zasadniczego zwrotu polegającego na tym, że przemawia On z mocą samego Boga - co doskonale wyczuwają Jego słuchacze - oraz że nie przychodzi znieść Prawa i Proroków, ale je wypełnia. ${ }^{5}$

Benedykt XVI podejmuje się również interpretacji słów Modlitwy Pańskiej. Przy wyjaśnianiu, co oznacza prośba skierowana do Boga, aby nie wiódł nas na pokuszenie, odwołuje się do Mt 4,ln., czyli sceny kuszenia Jezusa przez diabła, Hbr 2,18 i 4,15 mówiących o zmaganiach Jezusa, który przychodzi z pomocą tym, którzy doświadczają

4 Współczesny nurt indywidualistyczny w postrzeganiu człowieka utrudnia człowiekowi zrozumienie idei zastępstwa i wielkiej miłości Boga do człowieka. Banalizując zło i grzech, współczesny człowiek nie jest w stanie odczytać proroctwa Iz 53, 4-6 i dostrzec powiązań swojego życia z życiem ukrzyżowanego Zbawiciela; por. J. R a t z i n g e r - B e n e d y k t XVI, Jezus z Nazaretu, s. 139-142.

5 Por. tamże, s. 93-94. 
próby, Ap 12,10 wskazującej na prawdziwego oskarżyciela człowieka przed Bogiem oraz 1Kor 10,13 wyrażającego ufne przekonanie, że dobry Bóg wie, ile człowiek potrafi znieść i że zsyłając pokusę, wskazuje jednocześnie sposób jej pokonania. Autor Jezusa z Nazaretu zauważa też, że tajemnica Chrystusa zarysowuje się już w Księdze Hioba, pokazując także ważną prawdę, iż to nie Bóg doprowadza człowieka do upadku, ale pozwala na poddanie go próbie. Dzięki takim doświadczeniom powierzchowna pobożność może przemienić się w głębokie zjednoczenie człowieka ze swoim Stwórcą. ${ }^{6}$

Kolejną próbą wniknięcia w tajemnicę Chrystusa jest analiza słów, w których określa siebie jako dobrego Pasterza. Obraz ten - obecny w czterech Ewangeliach - był bardzo dobrze znany ludziom Bliskiego Wschodu (istnieją inskrypcje potwierdzające, że królowie asyryjscy i babilońscy postrzegali siebie jako pasterzy zesłanych przez Boga, aby sprawiedliwie zarządzali ludem). Stary Testament przynosi wiele świadectw mówiących o Bogu jako pasterzu, który sam szuka zagubionych owiec i troszczy się o swoje stado, np. Ps 23 czy Ez 34-37. Benedykt XVI akcentuje zwrot, jaki dokonał się u schyłku epoki starotestamentalnych proroków a prowadzący bezpośrednio do osoby Jezusa, mianowicie obraz zabitego pasterza $(\mathrm{Za} \mathrm{12,} \mathrm{10-11;} \mathrm{13,} \mathrm{1.7),} \mathrm{który}$ staje się Zbawicielem (Mt 26, 31). ${ }^{7}$

Interpretacja Kazania na Górze w Jezusie z Nazaretu nie jest szczegółowym skupianiem się nad każdym wypowiedzianym przez Chrystusa błogosławieństwem, ale wybraniem istotnych, według autora, motywów i wątków, które pozwalają uchwycić sens Jezusowego przekazu. Benedykt XVI rozumie błogosławieństwa jako nową Torę przyniesioną przez Jezusa, nowego Mojżesza, rozszerzającego Przymierze na wszystkie narody. Nauka Jezusa jest umocnieniem Dekalogu - przykazania zostają w niej pogłębione. Błogosławieństwa wpisują się także w długą, starotestamentalną tradycję obecną w psalmach (por. Ps 1) czy tekstach prorockich (por. Jr 17, 7n.) mówiących o pewnych drogowskazach pomagających żyć godnie i pełnić wolę

6 Por. tamize, s. 140-142.

7 Por. tamize, s. 229-231. 
Boga. W kontekście tych dwóch tekstów autor wyjaśnia również użycie przez ewangelistę Łukasza słów „biada”. Nie wyrażają one potępienia czy nienawiści, ale są ostrzeżeniem i troską o człowieka, którego koniec może być pozbawiony miłości przez wybór nieodpowiednich postaw. Benedykt XVI podkreśla konieczność interpretowania błogosławieństw przede wszystkim w kontekście biblijnym. ${ }^{8}$ Warto w tym miejscu zaprezentować kilka przykładów, które obrazują sposób posługiwania się metodą kanoniczną.

W poszukiwaniu odpowiedzi na pytanie kim są lub czym się charakteryzują „ludzie łaknący i pragnący sprawiedliwości” papież przywołuje bohatera Księgi Daniela, który został przez Wulgatę określony jako mąż pragnień (vir desideriorum). Do grona ludzi odznaczających się akceptacją rzeczywistości takiej, jaka jest, przy jednoczesnej tęsknocie i poszukiwaniu wyższych dóbr, ludzi będący na drodze prawdy i miłości prowadzącej ich ku Bogu Benedykt XVI zalicza Zachariasza i Elżbietę, Maryję i Józefa, Symeona i Annę, Mędrców ze Wschodu, apostołów czy św. Pawła. Błogosławiony jest głód, który prowadzi człowieka do Boga, nie uznaje własnych przekonań za głos sumienia, ale wsłuchuje się w głos samego Boga. ${ }^{9}$ Odpowiadając na pytanie, czy można błogosławić smutek, daje starotestamentalne świadectwo uzdrawiającego smutku obecne w Księdze Ezechiela (por. Ez 9, 4n.). Paradoksem staje się fakt, że ukazany tam rodzaj smutku stanowi antidotum na obecne w Jerozolimie zło. Można żyć wśród ludzi nikczemnych, można doświadczać niemocy dokonania jakiejkolwiek zmiany, ale zawsze można zachować bierny opór, cierpiąc na widok niegodziwości. Pod krzyżem Jezusa również odnajdujemy osoby, które pozostały wierne, nie uległy złu, lecz stanęły odważnie po stronie Boga-Miłości, współcierpiąc z Nim. ${ }^{10}$ Benedykt XVI, wyjaśniając z kolei, jak rozumiano termin „sprawiedliwość" w Starym Testamencie, przechodzi do jego znaczenia w Nowym Przymierzu. Sprawiedliwość, do której nawoływali pro-

\footnotetext{
Por. tamże, s. 66-71, 88, 90.

Por. tamże, s. 85-87.

10 Por. tamże, s. 82-83.
} 
rocy, polega na wierności słowu Boga czyli Jego Prawu, na chodzeniu Jego ścieżkami (por. Ps 1; Jr 17,5-8). Natomiast odpowiednikiem słowa „sprawiedliwość”, który przynosi Nowy Testament, jest słowo „wiara”. Ten, który podąża za Chrystusem i słucha Jego a nie świata, jest sprawiedliwy, a z tego też tytułu często doświadcza prześladowań ze strony świata, wolącego słuchać siebie niż Boga. ${ }^{11}$ Kończąc zagadnienie błogosławieństw w dziele Jezus z Nazaretu, można wskazać próbę wyjaśnienia paradoksu błogosławieństw w nawiązaniu do św. Pawła i św. Jana. Błogosławieństwa to obraz rzeczywistej sytuacji wierzących w Chrystusa: „Uchodzący za oszustów, a przecież prawdomówni, niby nieznani, a przecież dobrze znani, niby umierający, a oto żyjemy, jakby karceni, lecz nie uśmiercani, jakby smutni, lecz zawsze radośni, jakby ubodzy, a jednak wzbogacający wielu, jako ci, którzy nic nie mają, a posiadają wszystko" (2Kor 6, 8-10). Żyjąc duchem błogosławieństw, uczeń Chrystusa doświadcza w swoim życiu realizacji krzyża i zmartwychwstania. Jak to ujął Jan apostoł krzyż, symbol hańby, stał się miejscem wywyższenia i królowania Boga (por. J 12,32-33). ${ }^{12}$

Podobnie jak błogosławieństwa, tak i przypowieści są wnikliwie analizowane. Perspektywa egzegetyczna ujęta w nich jest niezwykle szeroka. Jednak mimo to, że w analizie tej Benedykt XVI odwołuje się do różnych spojrzeń i egzegez biblijnych, trzyma się jednocześnie wiernie założenia, że Ewangelie, podobnie jak cała Biblia, mimo różnic tradycji i historycznych uwarunkowań, zawierają wewnętrznie spójne orędzie. Według Benedykta XVI, podejmując nieustanny wysiłek odczytywania przypowieści na nowo, należy mieć na uwadze, że ostatecznie zostają one ,rozszyfrowane” na krzyżu. ${ }^{13}$

Egzegeza trzech przypowieści została poprzedzona wnikliwym wykładem na temat, jak rozumieć użyty przez Chrystusa termin „królestwo Boże". Papież, uwzględniając kontekst historyczny, nie ogranicza się jednak jedynie do egzegezy kanonicznej, gdyż - odwoławszy

\footnotetext{
Por. tamże, s. 84.

12 Por. tamże, s. 71-72.

13 Por. tamże, s. 165.
} 
się do rozumienia królestwa Bożego przez Ojców Kościoła i w historii Kościoła - przywołuje także stanowisko wypracowane przez egzegezę liberalną oraz zwolenników twierdzenia, że głoszenie królestwa Bożego należy pojmować ściśle eschatologicznie czy też że ideę królestwa należy postrzegać na sposób sekularystyczny jako wspólne budowanie świata. Dostrzegając w powyższych tezach ziarna prawdy, Benedykt XVI generalnie podejmuje z nimi polemikę, gdyż - jego zdaniem - ograniczają one głębokość rzeczywistości królestwa Bożego przyniesionego przez Jezusa. Sam uważa, że wszystkie pozornie sprzeczne ze sobą spojrzenia można połączyć w sensowną całość, przyjmując osobę Chrystusa, Jego królowanie przez miłość aż po krzyż. Dodatkowo Benedykt XVI uważa, że obecny w przepowiadaniu Jezusa temat królestwa Bożego można zrozumieć w kontekście całości Jego życia, a zwłaszcza relacji Ojciec - Syn. ${ }^{14}$

Jako konkretny przykład zastosowania egzegezy kanonicznej w interpretowaniu przypowieści można wskazać tę, która powszechnie znana jest jako przypowieść o synu marnotrawnym. Benedykt XVI zdecydowanie sympatyzuje jednak z innym nazewnictwem, mianowicie: przypowieść o dwu braciach i o dobrym ojcu (Łk 15,11-32). Zazwyczaj bowiem w egzegezie - jak wskazuje także pierwszy tytuł przypowieści - uwaga zostaje skupiona na synu, który porzuca dom rodzinny, gdy - jak podkreśla autor - przypowieść ta jest też i o drugim synu, który pozostaje (mimo że zgorzkniały) wierny ojcu. Następuje w przypowieści tej, zdaniem autora, wyraźne odwołanie się Pana Jezusa do przewijającej się w Starym Testamencie tematyki dwu braci: Kaina i Abla, Izmaela i Izaaka, Ezawa i Jakuba. Również ewangelista Mateusz przytacza przypowieść o dwu braciach, różniących się w swoich słowach i działaniach względem jasno wyrażonej woli ojca (por. Mt 21,28-32). Oprócz ludzkich postaw i zachowań braci Benedykt XVI porusza jeszcze kwestię postawy ojca - czyli obrazu Boga. Uwidacznia napięcie między obrazem miłosiernego i przebaczającego Boga, który przynosi Chrystusa, a zatwardziałością serca faryzeuszy. Zauważa jednak także, że obraz Boga, który lituje

14 Por. tamże, s. 51-63. 
się nad grzechem i nędzą człowieka czy ludu wybranego, obecny jest już w Starym Testamencie. Autor przywołuje Księgę proroka Ozeasza, która jest świadectwem odejścia Izraela od prawdziwego Stwórcy i oddawania czci innym bóstwom (por. Oz 11, 1-9). Grzechy wywołują Boży gniew, jednakże serce Boga gniew i karę zamienia w przebaczenie. ${ }^{15}$

W interpretacji kolejnej przypowieści o bogaczu i ubogim Łazarzu (por. Łk 16,19-31) Benedykt XVI szuka pomocy w psalmach. Łazarz należy do grona ubogich, którzy wznoszą do Boga głos, doświadczając niedoli i widząc pomyślność grzeszników (por. Ps 44). Trzeba mieć tu na uwadze także ewolucję rozumienia pomyślności i jej braku. Teza, że Bóg nagradza szczęściem sprawiedliwość, a karze nieszczęściem za grzech, załamała się na skutek niewoli babilońskiej. Teksty starotestamentalne tego okresu są poszukiwaniem odpowiedzi na pytanie o to, jaki jest Bóg i o Jego obecność pośród swego ludu. Autor Jezusa z Nazaretu upatruje w Ps 73 ,duchowego zaplecza” wyżej wymienionej przypowieści. Jest to skarga ubogiego, która rodzi się z zazdrości o pomyślność osób niegodziwych. Istnieje ryzyko utraty wiary, kiedy sprawiedliwy za swoje czyny doświadcza chłosty i utrapień. Jednak wyjście ku Bogu i spojrzenie z Jego perspektywy pozwala cierpiącemu człowiekowi na odkrycie prawdziwej mądrości. Życie człowieka może ograniczyć się jedynie do perspektywy ziemskiej i materialnej oraz zapomnienia o Bogu i życiu wiecznym. Jednakże tym, co przynosi prawdziwe szczęście nie tylko w perspektywie eschatologicznej, ale także już tu, na ziemi, jest życie w bliskości z Bogiem. ${ }^{16}$

\section{Metoda odwoływania się do żydowskich tradycji interpretacyjnych}

Innym, niezwykle istotnym elementem metody egzegetycznej Benedykta XVI są liczne odwołania się do żydowskich tradycji

15 Por. tamże, s. 174-178.

16 Por. tamże, s. 182-184. 
interpretacyjnych. ${ }^{17}$ Badania nad starożytną kulturą żydowską pokazują, jak bardzo świat ówczesnego judaizmu był złożony. Należy zaznaczyć, że słynni egzegeci chrześcijańscy, tacy jak Orygenes czy Hieronim, posługiwali się żydowską egzegezą w celu lepszego zrozumienia Biblii. Jest to jak najbardziej logiczne działanie, biorąc pod uwagę fakt, że Kościół i Nowy Testament rodziły się na gruncie judaizmu biblijnego. ${ }^{18} \mathrm{~W}$ tym miejscu należy jednak podkreślić, że wyznawcy Chrystusa czytali i interpretowali księgi Starego Testamentu przez pryzmat Osoby Jezusa, a zwłaszcza wydarzeń paschalnych. Lektura Prawa, Proroków i Pism biblijnego Izraela miała zatem charakter chrystologiczny. ${ }^{19}$ Autor dzieła Jezus z Nazaretu wchodzi w - oparty na szacunku i miłości - dialog z judaizmem, czerpiąc z jego doświadczenia wiedzę i mądrość, przy jednoczesnym podkreśleniu zasadniczego novum, które przynosi Jezus Chrystus.

Zgłębiając tajemnicę macierzyńskiej miłości Boga, Benedykt XVI wyjaśnia hebrajskie słowo rahamìm, czyli „matczyne łono”, które oznacza również „miłosierdzie Boga”. Przyzwyczajeni do abstrakcyjnych pojęć musimy mieć świadomość, że ważne prawdy były wyrażane w Starym Testamencie innym niż współcześnie językiem, mianowicie obrazowym językiem ciała. Papież mocno akcentuje prawdę, że w Biblii słowo „matka” nigdy nie było tytułem Boga ani kierowanym do Niego wezwaniem, lecz pewnym wzorem. Przyglądając się obecnemu w historii religii kultowi bogiń-matek, należy zaznaczyć, że ze swej natury cechował go panteizm, który był zawsze w opozycji do biblijnego obrazu Boga. Biblia, wyrażając prawdę, że Bóg nie jest ani mężczyzną, ani kobietą, nazywając Boga Ojcem

17 W. C h r o s t o w s k i, Żydowskie tradycje interpretacyjne pomoca w zrozumieniu Biblii, w: R. R u b i n k i e w i c z (tłum. i red.), Interpretacja Biblii w Kościele. Dokument Papieskiej Komisji Biblijnej z komentarzem biblistów polskich, Rozprawy i Studia Biblijne 4, Warszawa 1999, s. 131-146.

18 Por. Papieska Kom is ja Biblijna, Interpretacja Pisma Świętego w Kościele, Poznań 1994, s. 43-44.

19 W. Ch rostow s ki, Qumran w myśli teologicznej Benedykta XVI, w: H. D r a w n e 1, A. P i w ow a r (red.), Qumran - pomiędzy Nowym a Starym Testamentem, Analecta Biblica Lublinensia 2, Lublin 2009, s. 332. 
wyraża Jego absolutną transcendencję i suwerenność oraz różnicę między Stwórcą a stworzeniem. ${ }^{20}$

Odwołując się do żydowskiej interpretacji Tory, Benedykt XVI powołuje się na książkę rabina Jacoba Neusnera Rabbi rozmawia z Jezusem, która jest obrazem szczerego dialogu, jaki żydowski uczony, przekonany o słuszności judaizmu, podejmuje z chrześcijaństwem. Tym zasadniczym novum jest dla Neusnera tajemnicze utożsamianie się Jezusa z samym Bogiem, tak bardzo trudne do przyjęcia dla wyznawcy judaizmu. Można wskazać na zasadniczą różnicę w interpretowaniu trzeciego i czwartego przykazania Bożego przez Jezusa i judaizm jak również kwestię dotyczącą istoty świętości i doskonałości. ${ }^{21}$ Podejmując refleksję nad Prawem starożytnego Izraela i jego rozumieniem, odwołuje się do wyników badań współczesnych egzegetów wskazujących na podział prawa na kazuistyczne i apodyktyczne. Rozróżnienie to jest istotne, gdyż tłumaczy różnice w podejściu do norm prawnych, które mogą mieć charakter kazuistyczny, czyli możliwa jest ich zmiana, oraz apodyktyczny, gdyż zawierają istotne i niezmienne zasady prawa Bożego. Innymi słowy, zasady prawa Bożego są fundamentem, na którym tworzy się kazuistyczne normy tworzące społeczne struktury. Benedykt XVI na tle kwestii związanych z prawodawstwem i jego postrzeganiem w samej Biblii pokazuje osobę Jezusa Chrystusa jako tego, który jest profetycznym interpretatorem Tory, a nie jakimś buntownikiem czy liberałem. ${ }^{22}$

Ukazując silną jedność tajemnicy wcielenia i krzyża, Benedykt XVI zauważa obecną w Starym Testamencie ewolucję myśli judaistycznej dotyczącą postrzegania znaku chleba. Tematyka chleba przenika również Ewangelię i, aby dobrze zrozumieć słowa Jezusa, autor odwołuje się do starotestamentalnej rzeczywistości. Wędrujący przez pustynię lud otrzymał mannę, chleb z nieba, jednakże widzimy, że pisma Starego Testamentu wyrażają drogę tego ludu do innego przekonania, mianowicie że manna była jedynie chlebem ziemskim,

20 Por. J. R a t z i nge r- B e n e d y k t XVI, Jezus z Nazaretu, s. 123-125.

${ }_{21}$ Por. tamże, s. 95-114.

22 Por. tamże, s. 111-114. 
natomiast prawdziwym pokarmem stawało się słowo Boga, Jego Prawo. Owocem poznania i przestrzegania woli Bożej była radość i wdzięczność wyrażana m.in. w psalmach. Uczestnicy cudu rozmnożenia chleba nie zrozumieli „znaku”, przejęli rzeczywistość materialną, podczas gdy Jezus zaprasza swoich uczniów do czegoś o wiele bardziej głębokiego. Rzeczywistość karmienia się chlebem, którym jest On sam, jest dla nas darem Boga, który sam wydaje się W ręce ludzi. ${ }^{23}$

W celu lepszego zrozumienia tajemnicy Chrystusa i głębokiej interpretacji Jego słów Benedykt XVI interpretuje fragment o przemienieniu Jezusa w kontekście żydowskiego kalendarza liturgicznego. Przywołując polemiczną dyskusję między Jean Marie van Cangh a Michelem van Esbroeckiem, skłania się ku tezie, że wydarzenie to miało miejsce w ostatni dzień Święta Namiotów. Przez powiązanie wielkich wydarzenia z życia Jezusa z żydowskim kalendarzem świąt można, według autora, zaobserwować pewną prawidłowość, mianowicie że wydarzenie liturgiczne, które ma określoną tematykę i wiąże się z pewnymi oczekiwaniami, w Osobie Jezusa Chrystusa staje się żywą rzeczywistością. Dodatkowo należy jeszcze uwzględnić, że Święto Namiotów miało we współczesnym Jezusowi judaizmie wydźwięk mesjański. ${ }^{24} \mathrm{~W}$ dziele Benedykta XVI mamy jeszcze jedno odwołanie się do Święta Namiotów, mianowicie przy interpretacji fragmentu Ewangelii wg św. Jana, w której Jezus wypowiada obietnicę dania nowej wody, wody żywej, źródła, które zawiera w sobie całą pełnię. Podczas Święta Namiotów następował uroczysty obrzęd wylania wody na ołtarz, który nawiązywał do licznych tekstów Starego Testamentu (Ez 47, 1-12; Za 13, 1; 14, 8) i wizji nowej świątyni. Według Benedykta XVI wszystkie te teksty i wymowa Święta Namiotów wskazują nie tylko na Nowe Jeruzalem, ale również na tego, z którego ukrzyżowanego boku wypłynęła krew i woda, który jest

23 Por. tami̇e, s. 40, 224-227.

24 Por. tamize, s. 256, 261. 
świątynią nieuczynioną ręką ludzką, który jest żywym mieszkaniem Boga nie tylko w Jeruzalem, ale na całym świecie. ${ }^{25}$

\section{Egzegeza patrystyczna}

Ojców Kościoła można uznać za tych, którzy wnieśli ogromny wkład zarówno w formowanie samego kanonu Pisma Świętego, jak i jego interpretację. Szczególna waga egzegezy patrystycznej jest związana z faktem, że dzięki niej i w wyznaczonych przez nią kierunkach formowało się nauczanie doktrynalne Kościoła. Cechą istotną tej egzegezy był jej służebny charakter wobec wspólnoty ludzi wierzących, co pociągało za sobą jej rys teologiczny, pastoralny i teologalny - gdyż wszystko, co zostało spisane, zostało spisane dla naszego pouczenia (por. 1Kor 10,11). Warto jeszcze zaznaczyć, że przy generalnie stosowanej przez Ojców metodzie alegorycznej interpretacji Biblii sens literalny i historyczność tekstów były rzadko eliminowane. ${ }^{26}$

W przypadku części pierwszej Jezusa z Nazaretu możemy wskazać na zastosowanie kilku znaczących odwołań do Ojców Kościoła i pisarzy wczesnochrześcijańskich. ${ }^{27}$ Benedykt XVI przyznaje słuszność tezie stawianej przez Ojców Kościoła, że zwieńczające chrzest Jezusa zstąpienia na Niego Ducha Świętego jest analogią do obecnego w Starym Testamencie namaszczenia na proroków i kapłanów, przez które byli mianowani do spełniania określonego urzędu. ${ }^{28} \mathrm{~W}$ innym miejscu kardynał mówi o rozumieniu przez Ojców liczby 40 (cztery strony świata wyrażają całość, natomiast dziesięć to liczba przykazań)

25 Por. tamże, s. 205-209.

26 Por. Papieska Komis ja Biblijna, Interpretacja Pisma Świętego w Kościele, s. 82-84.

27 W adhortacji Verbum Domini z 2010 (por. nr 37-38) Benedykt XVI podkreśla zasadność przyglądania się podejściu egzegetycznemu Ojców Kościoła, w którym dominuje interpretacja ponadsłowna, ze względu na duchowe odczytywanie słów Pisma Świętego. Benedykt XVI podkreśla potrzebę tzw. hermeneutyki wiary, która nie ogranicza interpretacji Pisma Świętego jedynie do procesu intelektualnego.

28 Por. J. R a t z ing e r-B e n e d y k t XVI, Jezus z Nazaretu, s. 35. 
i uważa rozszerzanie symbolizmu za nieco sztuczne. ${ }^{29}$ Powołując się na Orygenesa, Benedykt XVI wskazuje na interesujący szczegół, mianowicie że osoba Barabasza, której uwolnienia domagał się tłum, przy jednoczesnym żądaniu skazania Jezusa na śmierć, do trzeciego wieku w wielu rękopisach Ewangelii funkcjonowała jako „Jesus-Barabbas”, co oznacza „Jezus syn ojca”. Mamy zatem jakby dwie formy mesjanizmu i jakby sobowtóra Chrystusa. ${ }^{30}$ Snując zaś interpretację nad rozumieniem terminu „królestwo” w dziejach Kościoła, autor Jezusa z Nazaretu wskazuje na istniejące u Ojców Kościoła trzy wymiary: wymiar chrystologiczny (autobasileia u Orygenesa), interpretację mistyczną i eklezjologiczną. ${ }^{31}$

Nawiązania do Ojców Kościoła są obecne również przy egzegezie przypowieści. W przypowieści o miłosiernym Samarytaninie zostaje przytoczona chrystologiczna interpretacja, według której obrabowany i pobity człowiek jest obrazem Adama, człowieka w ogóle, który wpadł w ręce złych ludzi i został przez nich pobity i wykorzystany. Pojedyncze szczegóły tej przypowieści były różnie przez Ojców interpretowane, jednakże główna myśl, że Samarytaninem jest Jezus, Bóg, który stał się bliski swojemu stworzeniu, ukazuje już, według Benedykta XVI, jej głęboki wymiar. ${ }^{32} \mathrm{~W}$ refleksji nad przypowieścią o bogaczu i Łazarzu papież wspomina o typologii stosowanej przez niektórych Ojców Kościoła odnoszącej się do relacji Izrael (bogacz) i Kościół (ubogi Łazarz), jednakże według niego taka optyka sprawia, że nie uwzględnia się całej głębi tej przypowieści. ${ }^{33}$ Również interpretując fragment J 7, 38: ,Jak rzekło Pismo: Strumienie wody żywej popłyną z jego wnętrza”, Benedykt XVI stawia pytanie: „Z czyjego wnętrza?" i przywołuje dwie różne odpowiedzi. Zapoczątkowana przez Orygenesa tradycja aleksandryjska (propagowana również przez Ojców łacińskich takich jak Hieronim czy Augustyn) idzie

\footnotetext{
29 Por. tami̇e, s. 38.

30 Por. tami̇e, s. 47.

31 Por. tamie, s. 53.

32 Por. tamze, s. 172-173.

33 Por. tamże, s. 181-182.
} 
w kierunku, że chodzi o wnętrze człowieka wierzącego, które dzięki wierze w Chrystusa staje się źródłem świeżej wody. Natomiast mniej znana tradycja małoazjatycka (poświadczona przez Justyna, Ireneusza, Hipolita, Cypriana czy Efrema) słowa ,z jego wnętrza” odnosi do ciała Chrystusa. Benedykt XVI, podsumowując, stwierdza, że o ile pierwsza interpretacja jest bardziej poprawna lingwistycznie i ma wielu zwolenników, to za drugą przemawia więcej argumentów merytorycznych. ${ }^{34}$ Teksty konkretnych Ojców Kościoła są przywoływane jeszcze w następujących kwestiach: powiązanie Święta Namiotów z wcieleniem u Grzegorza z Nyssy, Jezus jako pasterz w wierszach Klemensa Aleksandryjskiego czy interpretacje św. Cypriana dotyczące Modlitwy Pańskiej. ${ }^{35}$

Podsumowując kwestię odwołań Benedykta XVI w Jezusie z Nazaretu do biblijnej myśli patrystycznej, należy zwrócić uwagę, że autor nie korzysta z tekstów Ojców Kościoła w sposób akademicki, ale wykorzystuje je w sposób autorski i niesystematyczny. Sam sposób przywoływania pism Ojców jest również niejednolity. Czasami zdarza się, że informacje podane przez autora pozwalają znaleźć źródło, w innych przypadkach zakładają biegłą znajomość dzieł danego autora lub zmuszają do cierpliwych poszukiwań. ${ }^{36}$

\section{Alegoryczno-symboliczna interpretacja Biblii}

Studiując literaturę patrystyczną czy też średniowieczne teksty, zauważamy w nich bogactwo komentarzy biblijnych, w których autorzy szli dalej niż dosłowny tekst biblijny na to pozwalał. Taką interpretację Biblii, w której wykracza się poza sens bezpośrednio zapisany w słowach, można nazwać alegoryczną, duchową, mistyczną

34 Por. tamże, s. 208.

35 Por. tamże, s. 262, 238, 133, 134, 137, 142, 145.

36 Por. A. Ż u r e k, Patrystyczne ,źródła” Jezusa z Nazaretu Josepha Ratzingera-Benedykta XVI, w: J. K róli k ow s k i, P. Ł a b u d a, A. M i c ha li k (red.), Jezus z Nazaretu. Poszukiwania chrystologiczne droga wyznaczona przez Josepha Ratzingera - Benedykta XVI, Tarnów 2016, s. 60-61. 
czy ponaddsłowną (symbol pozwalał na przeniesienie się z tego, co widzialne $\mathrm{w}$ to, co niewidzialne, $\mathrm{w}$ tajemnice). ${ }^{37}$ Warto $\mathrm{w}$ tym miejscu wspomnieć o tej-zdecydowanie zapomnianej w nowożytnej egzegezie-metodzie interpretacji alegoryczno-symbolicznej. Zanim jednak zostaną zaprezentowane symbole, których interpretację podejmuje Benedykt XVI, trzeba przytoczyć krótką definicję symbolu biblijnego. Symbol jest czymś więcej niż znakiem informacyjnym, gdyż może dopuszczać różnoraką interpretację. Biblijny symbol spełnia cechy symbolu literackiego, czyli motywu lub zespołów motywów danego utworu, które, opierając się na znaczeniach podstawowych, budują znaczenie wtórne i bogatsze. W literaturze chrześcijańskiej Biblia ma niesamowitą moc symbolotwórczą, gdyż na przestrzeni wieków na podstawie jej motywów literackich zbudowano bogactwo znaczeń w tórnych. ${ }^{38}$

Benedykt XVI wyjaśnia między innymi symbolikę chrztu. Jest on zerwaniem z grzechem i przejściem do życia nowego. Obrzęd zanurzenia symbolizuje śmierć (np. wody potopu, ocean jako ustawiczne zagrożenie w starożytnym przekonaniu), z drugiej jednak strony rzeka jest potężnym źródłem życia (Nil, Eufrat, Tygrys, Jordan). ${ }^{39}$ Interpretując obrazy zawarte w Ewangelii św. Jana, zwraca także uwagę na ich różnorodną symbolikę. W Ewangelii Janowej spotykamy się bardzo często z symboliką wody - jej obraz zostaje przywołany m.in. w rozmowie Jezusa z Nikodemem, podczas spotkania Jezusa z Samarytanką przy studni Jakubowej, w historii uzdrowienia chorego nad sadzawką Siloe, przy obecności Jezusa na Święcie Namiotów, podczas którego następował uroczysty obrzęd wylania wody na ołtarz, obmycia nóg apostołom czy w wydarzeniu przebicia boku Mistrza. Krótkie omówienie scen ewangelicznych z szczególnym uwzględnieniem występującego $\mathrm{w}$ nich motywu wody poprzedzają

37 Por. K. B a r d s k i, Alegoryczno-symboliczna interpretacja Biblii, Kraków 2016, s. 11-14.

38 Por. tamże, s. 64-65.

39 Por. J. R a t z inge r-B e n e d y k t XVI, Jezus z Nazaretu, s. 28. 
w dziele Jezus z Nazaretu ogólne uwagi dotyczące symbolizmu wody w historii religii. ${ }^{40}$

Krzew winny i wino to kolejny element rozważań autora. O ile woda jest podstawowym pierwiastkiem dającym życie, kojarzonym z ludzką codziennością, o tyle wino jest symbolem świętowania. W judaizmie było używana podczas obrzędów Paschy, szabatu i wesela. Autor rozważa cud w Kanie Galilejskiej oraz motyw prawdziwego krzewu winnego występujący w mowach pożegnalnych Jezusa, odwołując się również do obrazu winnicy obecnego w Starym Testamencie w Księdze Izajasza czy też przypowieści o winnicy w Ewangelii św. Marka. W Nowym Testamencie symbol krzewu winnego i wina jest znakiem nadmiaru Bożych darów i wskazuje na ich nieodwołalność. Chrystus oczekuje od swoich uczniów, że owocem, który wydadzą, będzie miłość, a owoc ten jest możliwy jedynie dzięki oczyszczaniu dokonywanemu przez Boga. ${ }^{41}$

Można też mówić o symbolice miejsca, np. pytanie Jezusa za kogo uważają Go Jego uczniowie i wyznanie św. Piotra przez Mateusza i Marka jest umiejscowione w Cezarei Filipowej. Jest to miejsce, w którym Herod wybudował potężne sanktuarium dla bożka Pana (w dzisiejszym Banjas zachowały się jego ruiny). Dodatkowo Tradycja umieszcza tę scenę obok wysokiej skalnej ściany, która koresponduje ze słowami Jezusa o zbudowaniu Kościoła Chrystusowego na skale. Ponadto ewangeliści Marek i Łukasz podkreślają fakt, że Jezus był „w drodze”, że Jego nauczanie w Galilei dobiega końca i wyrusza w kierunku Jerozolimy, gdzie dokona się kulminacyjny moment zbawienia. ${ }^{42}$

Przemienienie Jezusa ma miejsce na górze Tabor. Góra w Piśmie Świętym jest uważana jako miejsce szczególnej bliskości z Bogiem (w Starym Testamencie - Synaj, Horeb, Moria to góry Bożego objawienia, w Nowym Testamencie - góra kuszenia, góra, gdzie Jezus wygłasza osiem błogosławieństw, góra modlitwy, Góra Oliwna,

\footnotetext{
40 Por. tamże, s. 202-206.

41 Por. tamie, s. 210-221.

42 Por. tamie, s. 243.
} 
Golgota, góra Wniebowstąpienia). Dodatkowo można przywołać widoczny w tle tych wydarzeń ogólny symbolizm góry jako miejsce podejmowania trudu zewnętrznego ale też i wewnętrznego, jako miejsce dostrzeżenia piękna świata i Jego Stwórcy. ${ }^{43}$

\section{Analiza semantyczna}

Inną z metod interpretacji tekstów biblijnych, jaką można wyodrębnić w Jezusie z Nazaretu, jest analiza semantyczna. Termin ją opisujący zaczął być używany dopiero w drugiej połowie XX w. - po opublikowaniu pracy Jamesa Barra Semantyka języka biblijnego sama metoda jednak istniała już od dawna, a stosowali ją m.in. bibliści tacy jak Hieronim czy Raszi. Analiza semantyczna opiera się na dwóch zasadniczych pytaniach: „Dlaczego autor w danym miejscu używa akurat takiego a nie innego słowa?” oraz: „W jaki sposób zmieniło się znaczenie używanego słowa - od sensu pierwotnie użytego - do współczesnego rozumienia?”. Istotne w niej jest również określenie kontekstu lingwistycznego i sytuacyjnego danego słowa lub fragmentu tekstu. Trzeba dodać, że zastosowanie osiągnięć współczesnej semantyki pozwala niewątpliwie zarówno lepiej przetłumaczyć jak i zrozumieć tekst biblijny, gdyż daje możliwość w ostatecznym procesie tłumaczenia słowa - przy uwzględnieniu różnic i niuansów języka greckiego czy hebrajskiego - określić jego znaczenie. $^{44}$

W nurcie omawianej metody interpretacji Pisma Świętego Benedykt XVI przeprowadził m.in. - wspomnianą już wyżej - analizę tłumaczenia imienia „Barabasz”. Z analizy tej wywiódł, że tłumaczenie tego imienia pozwala zrozumieć, iż na wybór (między Jezusem a Barabaszem) zgromadzonego przed Piłatem ludu można spojrzeć szerzej - jako na wybór pomiędzy dwiema formami mesjanizmu.

43 Por. tamże, s. 257.

44 Por. J. F. A. S a w y e r, Semantyka, w: R. J. Cogg in s, J. L. H o u ld e n (red. nauk.), W. Ch ros tow s k i (red. nauk. wyd. pol.), Stownik hermeneutyki biblijnej, Warszawa 2005, s. 766-768. 
Czytamy bowiem, że Barabasz był „zbrodniarzem” - przy czym grecki termin mówi tu raczej o „rozbójniku”. Ze względu zaś na fakt, że w sytuacji politycznej Palestyny słowo to oznaczało „bojownika ruchu oporu", można wysnuć tezę, że wybór ludu dokonuje się między ideą mesjasza, który walcząc, obiecuje wolność i królestwo, a ideą Mesjasza, który głosi, że prawdziwe życie poprzedza obumarcie dla siebie i swoich wizji. ${ }^{45}$

W innym miejscu, analizując termin „królestwo Boże”, Benedykt XVI zwraca uwagę na pewną kwestię semantyczną i - odnosząc się do języków oryginalnych - wykazuje niedoskonałość takiego przekładu. Mianowicie pisze o tym, że hebrajskie malkut i greckie $b a-$ sileia wskazują przez zastosowaną formę nomen actionis na funkcję królewskiego panowania. Tego „królestwa” nie trzeba kreować, ono nie przychodzi, ale jest formą panowania Boga nad światem. Jezus, głosząc je, głosi prawdę o Bogu, o Jego istnieniu, o Jego konkretnym działaniu w czasie i historii. Zatem zamiast terminu „królestwo Boże” lepsze byłoby użycie określeń ,panowanie Boga” lub „Jego rządy”. ${ }^{4}$

Przy komentarzu do Modlitwy Pańskiej Benedykt XVI podejmuje problematykę tłumaczenia i rozumienia słowa, które w Biblii występuje tylko jeden raz - greckiego epiousios, przetłumaczonego jako ,powszedni”. Papież przytacza wypowiedź Orygenesa (†254 r.), mistrza języka greckiego, który twierdził, że poza tym jednym miejscem w Piśmie Świętym słowo to nie pojawiło się w ogóle w grece, gdyż zostało utworzone przez ewangelistów. Mimo że odnaleziono w papirusie pochodzącym z V w. jedno świadectwo tego słowa, to ciągle za mało, by być pewnym jego zrozumienia, dlatego nieodzowne pozostaje badanie etymologii i kontekstów. Jedna z głównych interpretacji twierdzi, że słowo epiousios oznacza to, co „na bieżąco” potrzebne do życia; druga natomiast opowiada się za przekładem „przyszły (na dzień następny) chleb”. Druga interpretacja wydaje się trudna do pogodzenia z rzeczywistością ucznia Jezusa, chyba że widzi się ją w kontekście eschatologicznym - a wtedy staje się

45 Por. J. R a t z i nge r- B e n e d y k t XVI, Jezus z Nazaretu, s. 47.

46 Por. tamże, s. 58. 
prośbą o antycypowanie przyszłego świata. Te dwa spojrzenia pozornie siebie wykluczające - połączone ze sobą dają bogactwo i głębię znaczenia. Wychodząc od pokornej prośby o chleb codzienny, wpatrując się w dobrego Ojca, który troszczy się o swoje stworzenia, przychodzimy do tego, który stał się prawdziwym Chlebem z nieba i daje siebie w Eucharystii. ${ }^{47}$

Kolejnym przykładem zastosowania analizy semantycznej przez Benedykta XVI jest wyjaśnienie greckiego terminu użytego w przypowieści o synu marnotrawnym, tłumaczonego w Piśmie Świętym jako „roztrwonienie majątku”. Autor Jezusa z Nazaretu zwraca uwage na fakt, że w języku greckich filozofów słowo to oznaczało ,istotę”, w związku z tym interpretuje działania młodszego syna nie tylko w kategorii roztrwonienia dóbr materialnych, ale przede wszystkim zagubienia swojej „istoty” - tj. zagubienia siebie. Pragnąc wolności, rozumianej jako przejaw niczym nieskrępowanej samowoli, młodszy syn skończył jako niewolnik pasący świnie. ${ }^{48}$

\section{Polemika z nurtem historyczno-krytycznym}

Historyczno-krytyczna metoda badań nad Biblią jest wskazywana przez Papieską Komisję Biblijną jako nieodzowna. Patrząc na Biblię jako tekst starożytny, można posłużyć się naukowymi metodami, które przybliżają współczesnemu odbiorcy proces powstawania samego tekstu, czyli etapy redakcji, dane o autorze i adresatach, informacje o środowisku, w którym tekst powstawał oraz zrozumienie, co autor chciał przekazać pierwotnym czytelnikom. Wszystkie te formy metod egzegetycznych zwane diachronicznymi (z gr. ,przez czas”) noszą nazwę metody historyczno-krytycznej. Określenie „historyczna” wynika z podejmowanych prób ustalenia dość skomplikowanego i długotrwałego procesu powstawania tekstu starożytnego, natomiast „krytyczna” jest przyjmowane ze względu na

\footnotetext{
47 Por. tamże, s. 135.

48 Por. tamże, s. 175-176.
} 
użycie obiektywnych kryteriów naukowych. ${ }^{49}$ Metoda ta niewątpliwie pozwala na wolność $\mathrm{w}$ procesie interpretacji i na wyzwolenie się od opinii, twierdzeń czy sposobu interpretacji konkretnych sformułowań biblijnych przez wspólnoty chrześcijańskie. Jednakże posunięta zbyt daleko doprowadza do pomniejszenia roli Ludu Bożego i jego założeń wiary oraz do wykluczenia łączności pomiędzy doktryną Kościoła a tekstem Pisma Świętego. Dlatego też narodziny egzegezy kanonicznej, za której prekursorów uznaje się B. S. Childsa i J. A. Sandersa, uważa się za reakcję na pewne nadużycia historyczno-krytycznej metody w egzegezie. ${ }^{50}$

Jako przykład otwartości Benedykta XVI na dokonania współczesnej nauki i wykorzystanie jej zdobyczy w teologii można wskazać na istnienie w Jezusie z Nazaretu zagadnienia odkryć z Qumran. Mówiąc o wspólnocie qumrańskiej, papież zwrócił uwagę na różnorodność judaizmu z czasów Jezusa, odejście od kultu świątynnego przez esseńczyków, związki z Qumran między Janem Chrzcicielem i Jezusem oraz liczne analogie ze wspólnotą chrześcijańską. Zauważył, że wspomniane powiązania są jednak jedynie pewnymi hipotezami, które wymagają dalszych dociekań naukowych. ${ }^{51}$

W rozważaniach Benedykta XVI na temat osoby Jezusa z Nazaretu jest bardzo widoczny szacunek do historii i odkryć naukowych, które mogą być pomocą w interpretowaniu Biblii. Jak już zostało określone we Wstępie przez samego autora Jezusa z Nazaretu, nie kwestionuje on zasadności korzystania z metody historyczno-krytycznej, ale wskazuje na pewne ograniczenia lub wchodzi w polemikę z konkretnymi tezami stawianymi przez osoby uprawiające ten model egzegezy. Zastrzeżenie, jakie się pojawia, dotyczy przede wszystkim

49 Por. R. B a r t n i c k i, K. K łó s e k, Metody interpretacji Nowego Testamentu. Wprowadzenie, Kraków 2014, s. 12-16.

50 Por. A. S a n e c k i, Między uniwersytetem a Kościołem. Interpretacja kanoniczna w perspektywie eklezjalnej lektury Biblii, w: S. S z y m i k (red.), Stowo Boże w życiu i misji Kościoła, Analecta Biblica Lublinensia IV, Lublin 2009, s. 310-311.

${ }_{51}$ Por. W. Ch ro st ow s k i, Qumran w myśli teologicznej Benedykta XVI, s. 336-339. 
ograniczania spojrzenia na tekst biblijny jedynie w kontekście historycznym, pomijając rzeczywistość wiary.

W rozdziale pt. Orędzie przypowieści Benedykt XVI stwierdził, że trud właściwego zrozumienia przypowieści jest widoczny w całej historii Kościoła, nie zmienia to faktu, że współcześni wyznawcy Chrystusa na nowo muszą zadawać sobie pytanie, jakie przesłanie kieruje do nich dziś Jezus. Trudno o dostarczenie definitywnych odpowiedzi, bo nawet - jak to zaznaczył autor - egzegeza historyczno-krytyczna musiała korygować swoje wcześniejsze ustalenia. Benedykt XVI przywołuje dwutomowe dzieło Adolfa Jülichera poświęcone przypowieściom, w którym postawił on tezę, że istnieje zasadnicza różnica między alegorią i przypowieścią. Według Jülichera przypowieści Jezusa nie są alegorią, którą można interpretować jako obraz, za którym kryje się głębsze przesłanie, lecz jedynie przedstawieniem pewnego wycinka rzeczywistości, który ma posłużyć do wyrażenia ogólnej myśli. Dodatkowo alegoryczne interpretacje przypowieści podawane przez Jezusa (np. o siewcy) były traktowane jako późniejsze redakcje uczniów. Benedykt XVI przyznaje rację, że sam zabieg oddzielenia literackiego gatunku alegorii i przypowieści jest słuszny, jednak zauważa także, że tak radykalnego oddzielenia nie da się wyjaśnić ani merytorycznie, ani historycznie, gdyż przypowieść i alegoria mogą przechodzić jedna w drugą. Dodatkowo zauważa, że hebrajskie słowo mashal oznaczające przypowieść określa najrozmaitsze gatunki takie jak: „przypowieść”, „porównanie”, „baśń”, „alegorię”, „symbol”, „fikcję” czy „zagadkę”. Nie zgodził się również z ograniczeniem celu przypowieści jedynie do zapowiedzi mającego nadejść królestwa Bożego - jak zaproponował Jülicher. ${ }^{52}$

Benedykt XVI w Jezusie z Nazaretu odniósł się także do kwestii związanych z historycznością Ewangelii według św. Jana. Komentarz R. Bultmanna z 1941 r. reprezentował przekonanie, że źródeł tej Ewangelii należy szukać w nurcie gnostyckim, a nie w Starym Testamencie czy judaizmie bliskim Jezusowi. Pod ogromnym wpływem tego komentarza pozostawała interpretacja czwartej Ewangelii. Przełom

52 Por. J. R a t z inge r- B e n e d y k t XVI, Jezus z Nazaretu, s. 159-162. 
w naukowej krytyce pism Jana dokonał się pod koniec XX w., kiedy M. Hengel opublikował swoją pracę Die johanneische Frage (1993). Jeśli na krytyczną refleksję Bultmanna dotyczącą pism Janowych spojrzeć z perspektywy dzisiejszych badań, można stwierdzić, że nie uniknęła błędów. W wielkim skrócie można wskazać na następujące czynniki, które jej przeczą: ramy czasowe ruchu gnostyckiego, znajomość realiów Palestyny czasów Chrystusa przez autora, sposób argumentowania znany judaizmowi współczesnemu Jezusowi czy język. Trudności budziło również pytanie o prawdziwego Autora oraz redakcję Ewangelii, gdyż brak jasnej odpowiedzi podważał jej historyczność. W odpowiedzi na tę kwestię Benedykt XVI przedstawił argumenty za tezą, że autora czwartej Ewangelii, „umiłowanego ucznia", można utożsamić z apostołem Janem, naocznym świadkiem opisywanych w Ewangelii wydarzeń. Papież wspomina także o prezbiterze Janie, który był ściśle związany z apostołem Janem i mógł pełnić istotną funkcję przy redakcji - jako powiernik tradycji otrzymanej od niego. Benedykt XVI zmierza się jeszcze z negatywną diagnozą postawionej przez M. Hengela dotyczącej historyczności tekstu Ewangelii. Hengel przeciwstawia sobie pojęcia historyczności $\mathrm{i}$ interpretacji w wierze, nad którym to procesem czuwa Duch Święty. Taka opozycja pojęć jest dla Benedykta XVI fałszywym rozumieniem zarówno historyczności, jak i pojęcia wiary i Parakleta. Wiara, która pomija autentyczną historię, przestaje być wiarą a zaczyna być gnozą. Natomiast w oczekiwaniach współczesnego człowieka i jego pojmowaniu historyczności mów Jezusa jest pewien dysonans, gdyż nie jest to wierne odtworzenie słowo w słowo tego, co wypowiedział Chrystus. Jednakże nie taka dosłowność była zamiarem Ewangelisty, ale to, żeby przez rzetelne przekazanie treści mów i świadectwa przekazać autentyczne przesłanie Chrystusa i aby przez nie poznać Jego samego. Kończąc rozważania na temat historyczności Janowej Ewangelii, Benedykt XVI podejmuje ważną kwestię znaczenia pamięci i rozumienia zwrotu ,przypomnieć sobie” w jego Ewangelii. Uczniowie, dzięki dokonywanemu w Duchu Świętym procesowi przypominania pewnych słów czy wydarzeń, rozumieją dany fakt w zupełnie innym świetle, głębiej. Po zmartwychwstaniu Chrystusa 
uczniowie przypominali sobie słowa Mistrza i zaczynali je postrzegać z zupełnie innej perspektywy, w minionym fakcie dostrzegli ukrytą prawdę pochodzącą od Boga. Ten proces przypominania sobie, który dokonuje się w uczniach, nie jest budowaniem narracji o wydarzeniach, które nie miały miejsca, ale trzymaniem się rzeczywistości, która miała realnie miejsce w przeszłości. ${ }^{53}$

Benedykt XVI porusza jeszcze jedną, istotną kwestię, mianowicie podejmowane przez naukę historyczne rekonstrukcje (np. dotyczące wyznania Piotra w Cezarei Filipowej) czy dyskusje nad problemem, który tekst jest pierwotny (jak w przypadku Modlitwy Pańskiej przekazanej przez Mateusza i Łukasza). Benedykt XVI zauważa, że w tle tych dyskusji zawsze jest pytanie, jaki wpływ na tekst miał rozwój wiary popaschalnej, i jednocześnie stwierdza, że taka wiara nie mogłaby się pojawić, gdyby Jezus przed Paschą nie położył pod nią fundamentów. Przywołując interpretację katolickiego egzegety Pierre'a Grelota na temat historycznego przekazu słów św. Piotra i przedstawiając stawianą przez niego tezę, że jedynie Marek oddał wiernie ten moment historyczny, podczas gdy u Mateusza mamy już popaschalne wyznanie wiary, Benedykt XVI przeanalizował odpowiedzi dawane przez Nowy Testament i tradycję zawartą w każdej Ewangelii oraz naukę dotyczącą dwóch formuł wyznawania wiary w pierwotnym chrześcijaństwie. W swoich rozważaniach autor poruszył jeszcze kwestię podważania przez krytykę autentyczności słów Jezusa, który jako Syn Człowieczy utożsamia się z ubogimi i cierpiącymi (por. Mt 25,31-46). Zaufanie niektórych krytyków zdobyły fragmenty Łk 12,8n. i Łk 17,24n. zapewne ze względu na to, że Jezus i Syn Człowieczy są dwiema różnymi postaciami. Benedykt XVI podobnie jak w poprzedniej kwestii powołuje się na rozumienie tych zagadkowych słów przez najstarszą tradycję i paralelne teksty Nowego Testamentu wskazujące na bytową tożsamość Jezusa i Syna Człowieczego. ${ }^{54}$

\footnotetext{
53 Por. tamże, s. 188-200.

54 Por. tamże, s. 119, 246-251, 253, 272-273.
} 


\section{Polemika z egzegezą liberalną}

Egzegeza liberalna - pozostająca pod wpływem filozofii Kanta i Schleiermachera - narodziła się w kręgu niemieckich biblistów protestanckich. Jej wybitnym przedstawicielem był A. Ritschla (1822-1889) - zdecydowany przeciwnik metafizyki i mistycyzmu w religii. Udowadnianie tezy Ritschla, że chrześcijaństwo w swoim rozwoju historycznym przyswoiło sobie elementy obce, niezgodne z Ewangelią, kontynuował jego uczeń A. Harnack. Przeciwstawił on „czyste chrześcijaństwo” w wersji ewangelicznej całej strukturze dogmatycznej, kultowej i instytucjonalnej chrześcijaństwa w czasie pobiblijnym. Liberalna egzegeza straciła swoje znaczenie w latach dwudziestych XX w. ${ }^{55}$

Autor Jezusa z Nazaretu przedstawił kilka wątków związanych z opisaną egzegezą. Przytoczył m.in. nazwisko jej reprezentanta, A. Harnacka, i jego koncepcje interpretacyjne. Harnack widział w głoszeniu przez Jezusa królestwa Bożego zdecydowany protest przeciw legalizmowi - w którym dominował kult i poczucie zbiorowości - ówczesnego judaizmu,. Twierdził także, że Jezus głosił indywidualizm i kładł nacisk na etyczną postawę człowieka, na uczynki miłości. Benedykt XVI poddał krytyce dalsze wnioski niemieckiego biblisty, który przeciwstawił chrześcijaństwo rzymskokatolickie oraz greko-słowiańskie germańsko-protestanckiemu, w którym - według niego - została przywrócona czystość Chrystusowego orędzia. Papież zwrócił bowiem uwagę na fakt, że w niektórych wspólnotach protestanckich istniały mocne przekonania, że adresatem objawienia nie jest jednostka, ale wspólnota a w niej każdy wierzący, jako jej członek, oraz że życie wieczne nie jest uzależnione od zachowań etycznych, lecz jest darem łaski. ${ }^{56}$ Nazwisko Harnacka i nawiązanie do egzegezy liberalnej pojawia się w Jezusie z Nazaretu jesz-

55 Por. B. M. G. R e a r d o n, Liberalizm, w: R. J. C o g g i n s, J. L. H o u ld e n (red. nauk.), W. Ch ros tow s k i (red. nauk. wyd. pol.), Stownik hermeneutyki biblijnej, s. 503-505.

56 Por. J. R a t z ing e r - B e n e d y k t XVI, Jezus z Nazaretu, s. 54-55. 
cze w dwóch kontekstach. Pierwszy z nich dotyczy interpretowania sporów Jezusa z faryzeuszami o szabat. Według Benedykta XVI Jezus nie jest liberalnym interpretatorem Prawa, nie czyni tego, żeby człowiekowi ułatwić życie, ale wskazuje na siebie jako Pana szabatu, Pana - czyli Boga. Dlatego - według autora - Harnack i idąca za nim egzegeza liberalna bardzo się myli, twierdząc, że w Ewangelii znajdujemy Jezusa, a nie możemy znaleźć Syna czy Chrystusa, a więc Boga. ${ }^{57}$ Druga kwestia dotyczy postulatu uwolnienia Nowego Testamentu od dziedzictwa Starego Testamentu. Jest to postulat znany już od Marcjona a współcześnie objawiający się tendencją do czysto duchowej lektury Biblii bez nawiązań do społecznych czy politycznych uwarunkowań czasów, w których żył Jezus i wspólnota pierwszych chrześcijan. Taką tendencję papież określił jako zdecydowanie szkodliwą. ${ }^{58}$

Benedykt XVI, kończąc rozdział pt. Chrzest Jezusa, nawiązał do liberalnych badań dotyczących tego wydarzenia - które generalnie interpretują je jako doświadczenie powołania, moment wstrząsu i narodzin w Jezusie świadomości głębokiej relacji do Boga - i podjął polemikę z takimi stwierdzeniami. Zauważył, że sam tekst nie opowiada tego, co w tym momencie dokonało się we wnętrzu Jezusa, dlatego też twierdzi, iż posługiwanie się psychologią jest nieuprawnione i staje się nadużyciem. Według Benedykta taka interpretacja tego wydarzenia może stwarzać pozory erudycji, ale jest bardziej tworzeniem pewnej opowieści o Jezusie niż interpretacją tekstu. ${ }^{59}$

Poruszając kwestię interpretacji Biblii, Benedykt XVI zwrócił uwagę na podstawowy, jego zdaniem, problem hermeneutyczny, to jest obraz samego Boga. Papież otwarcie określa jako błędną drogę w egzegezie dokonującą się na bazie pozornych osiągnięć naukowych egzegezy dekonstrukcję postaci Jezusa i osłabianie wiary. Ryzyko współczesnej egzegezy polega na tym, że opiera się ona na założeniu, że to interpretujący decyduje, jaki Bóg jest i co Bóg może czynić.

\footnotetext{
57 Por. tamże, s. 101.

58 Por. tami̇e, s. 110.

59 Por. tamże, s. 34.
} 
Natomiast na czytanie Pisma Świętego w duchu wiary tenże model egzegezy patrzy jak na fundamentalizm. ${ }^{60}$

Benedykt XVI przedstawia książkę o Jezusie Chrystusie jako „owoc swojej długiej wewnętrznej drogi”. Wysiłek zmierzał do odpowiedzi na pytanie: Kim jest Jezus? Odpowiedź wyszukana na drodze analizy Pisma Świętego i Tradycji doprowadziła do stwierdzenia niepowtarzalności Osoby Jezusa jako prawdziwego Boga i prawdziwego Człowieka. Papież zaznaczył jasno, że żadna z biblijnych metod interpretacyjnych nie może rościć sobie prawa do stwierdzenia, iż jest w stanie podać jedynie słuszne informacje czy przynieść definitywne odpowiedzi. Żywe słowo Boże nieustannie wzywa nas do podjęcia trudu egzegezy, aby móc na nowo wyznaczać nam drogę do Boga. Wiara jest - dla Benedykta XVI - w interpretacji Pisma Świętego kwestią priorytetową, dlatego tak często odwołuje się w Jezusie z Nazaretu do metody kanonicznej. Jednocześnie wiara nie jest według niego sprawą indywidualną - lecz rodzi się we wspólnocie ludu, który doświadczył działania Bożego i je dalej przekazuje - dlatego stosuje tak liczne odwołania do tradycji patrystycznej. Objawienie dokonało się także w konkretnej rzeczywistości historycznej, zatem do właściwej interpretacji Biblii niezbędna jest, według Benedykta, znajomość środowiska i czasów, w których Jezus działał i w których powstawały księgi natchnione. Otwartość i determinacja, wynikające z pragnienia poznania prawdy, zaowocowała także tym, że Benedykt XVI w swojej książce przytacza bardzo często poglądy, z którymi się nie zgadza, ale podejmuje z nimi merytoryczną polemikę.

60 Por. tamże, s. 43. 
Słowa kluczowe: Jezus z Nazaretu; metody interpretacji Biblii; egzegeza kanoniczna; wiara; Benedykt XVI

Keywords: Jesus of Nazareth; methods of Bible interpretation; canonical exegesis; faith; Benedict XVI

\section{Model of Exegesis in the Book of Joseph Ratzinger - Benedict XVI Jesus of Nazareth Part 1}

Summary

This article presents the method of Bible interpretation which was chosen by Benedict XVI in his book Jesus of Nazareth pt. 1. Using this method, Joseph Ratzinger was looking for an answer to the question about the true identity of Jesus Christ. In this article, the author makes an attempt to present examples of the Pope's use of various exegetical methods. This helps us to understand Benedict's opinion which in his book is clearly stated, namely there is no single correct method of Bible interpretation which gives us definitive answer. Frequent references to the canonical method result from the fact that for Benedict XVI faith remains a priority for in the interpretation of the Holy Scriptures in the Catholic Church. Skillfully drawing from the treasury of Tradition and contemporary development of knowledge, the Pope engaged substantially in polemics with these interpretative tendencies, which in his opinion do not lead to the discovery of biblical truths. 